\title{
Intensification of Power Quality Using PMSG and Cascaded Multi Cell Trans-Z-Source Inverter
}

\author{
E. Rajendran1,2, Dr. C. Kumar³, Dr. P. Suresh4 \\ ${ }^{1}$ Anna University, Chennai, India \\ ${ }^{2}$ Department of EEE, SKP Engineering College, Tiruvannamalai, India \\ ${ }^{3}$ Sri Ranga Poopathi College of Engineering, Alampoondi, India \\ ${ }^{4}$ National College of Engineering, Tirunelveli, India \\ Email: rajendranvg1320@gmail.com,drchkumararima@gmail.com
}

How to cite this paper: Rajendran, E., Kumar, Dr.C. and Suresh, Dr.P. (2016) Intensification of Power Quality Using PMSG and Cascaded Multi Cell Trans-Z-Source Inverter. Circuits and Systems, 7, 3778-3793. http://dx.doi.org/10.4236/cs.2016.711316

Received: May 6, 2016

Accepted: May 20, 2016

Published: September 16, 2016

Copyright $\odot 2016$ by authors and Scientific Research Publishing Inc. This work is licensed under the Creative Commons Attribution International License (CC BY 4.0).

http://creativecommons.org/licenses/by/4.0/

\begin{abstract}
This script depicts the power quality intensification of Wind Energy Transfer System (WETS) using Permanent Magnet Synchronous Generator (PMSG) and Cascaded Multi Cell Trans-Z-Source Inverter (CMCTZSI). The PMSG knocks the induction generator and earlier generators, because of their stimulating performances without taking the frame power. The Trans-Z-Source Inverter with one transformer and one capacitor is connected newly. To increase the boosting ratio gratuity a cascaded impression is proposed with adopting multi-winding transformer which provides an option for this manuscript to use coupled inductor as an alternative of multi-winding transformer and remains the matching voltage gain as cascaded multi cell trans-Zsource inverter. Accordingly the parallel capacitances are also balancing the voltage gain. The parallel correlation of the method is essentially to trim down the voltage stresses and to improve the input current gain of the inverter. By using MALAB Simulation, harmonics can be reduced up to $1.32 \%$ and also DC side can be boosted up our required level $200-1000 \mathrm{~V}$ achievable. The new hardware setup results demonstrate to facilitate the multi cell Trans Z-source inverter. This can be generated high-voltage gain $[50 \mathrm{~V}-1000 \mathrm{~V}]$ and also be credible. Moreover, the level of currents, voltages and Harmonics on the machinery is low.
\end{abstract}

\section{Keywords}

Neuro Fuzzy System (NFS), Permanent Magnet Synchronous Generator (PMSG), Cascaded Multi Cell Trans-Z-Source Inverter (CMCTZSI), Wind Energy Transfer System (WETS) 


\section{Introduction}

Up to the minute years, a collection of career has been done in intensification of power quality using unpredictable generators and power electronics line of attack. Little scale stand-alone wind energy transfer system is leading an additional source of electrical force, finding the applications of a location, where predictable generation is not reasonable. Unfortunately, most of the systems cannot communicate power at each wind speed predominantly low wind speeds which are low in power, but they are entirely frequent. But brand new PMSG technology gives high success power translation that is mechanical force into electrical power. In this analysis to realize the PM generator systems is accessible for this purpose. Among the generators that are used in wind turbines, the PMSGs have the top compensation. Since they are steady state and protected during usual operation, they do not need a complementary DC supply for the excitation circuit (winding). In the normal voltage source and current source inverter, just convert AC to DC only. But we cannot make any other boost operations. But we can make only buck operation [1] [2]. The above drawback should be overcome the normal Z-Source inverter so, we can make buck and boost operation [3] [4]. Compared to Z-Source inverter, the output voltage of Quasi Z-Source inverter is high [5]. In qZSI, the shoot through state is used to boost up the magnetic power stored in the DC side inductors $L_{1}$ and $L_{2}$ without any short circuit in the DC capacitor $C_{1}$ and $C_{2}$. Compared to Quasi ZSource inverter, Trans-Z-Source inverter has more voltage gain, reduces the switching stress and also reduces less harmonics content [6].

Figure 1 below shows the conversional Trans-ZSI where the inductors in the original Z-Source Inverter are replaced by the transformers. It consists of two transformers $\left(T_{1}\right.$ and $\left.T_{2}\right)$, two capacitors $\left(C_{1}\right.$ and $\left.C_{2}\right)$, and one diode $\left(D_{i n}\right)$. The most important individuality of the proposed Trans-ZSI is as follows:

1) The fundamental $X$-shape arrangement is retained.

2) Only two transformers are used, and a very higher boost voltage gain can be obtained by changing the turn ratio of the transformers.

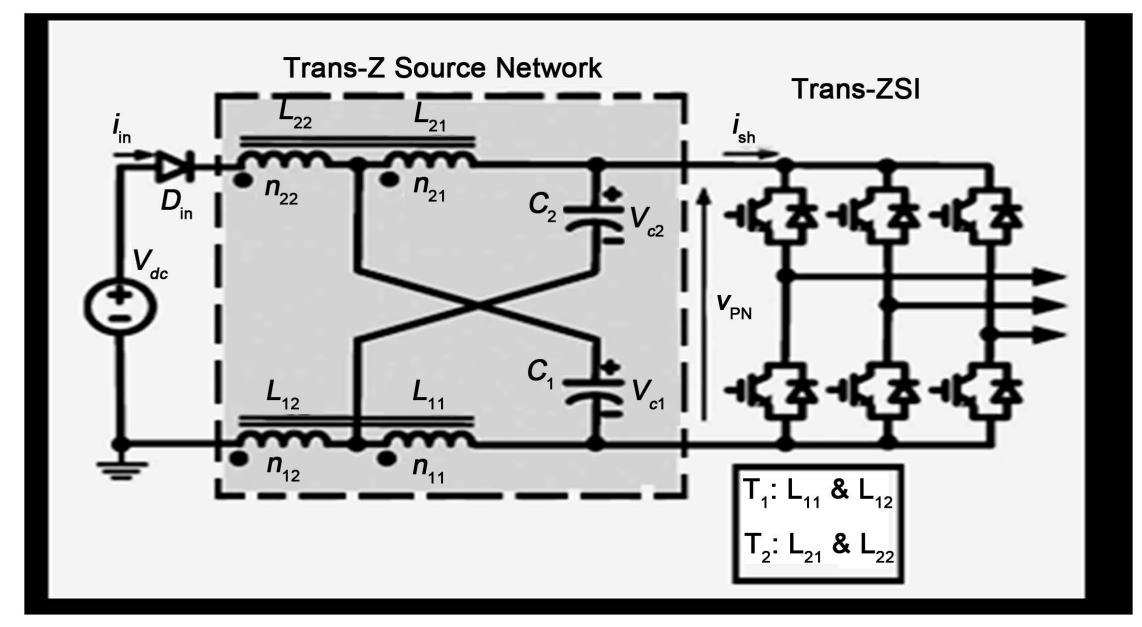

Figure 1. Conventional trans-Z-source inverter. 
3) While producing a high boost factor, the proposed Trans-ZSI does not utilize any extra diodes, which reduces its range, price, and loss compared to conventional voltage source and current source inverters.

4) It can be extended to the quasi Z-Source Inverter topologies to get better input current shape and place a lower voltage strain on capacitors.

The conventional inverter [7], like also less voltage gain and more harmonics, compared to propose Cascade Multi Cell Trans Z Source Inverter, is an option power conversion concept, while it can have mutually voltage buck and enhance capability. In addition to that, it has the successive compensation: protection to EMI noise, no in-rush current and misfiring compared to the predictable converter.

The multi cell trans-Z-source inverter is shown in Figure 2 below. This inverter has an impedance association on its DC side, which connects the foundation to the inverter. The impedance network is collected of two inductors and two capacitors. The predictable voltage source inverters have six active vectors and two zero vectors. Conversely, the multi cell trans-Z-source inverter has one extra zero vector (state) for boosting voltage that is called as a shoot-through vector. In this state, load terminals are shorted during mutually the upper and lower devices of in the least one phase leg, any two-phase legs, or all three-phase legs.

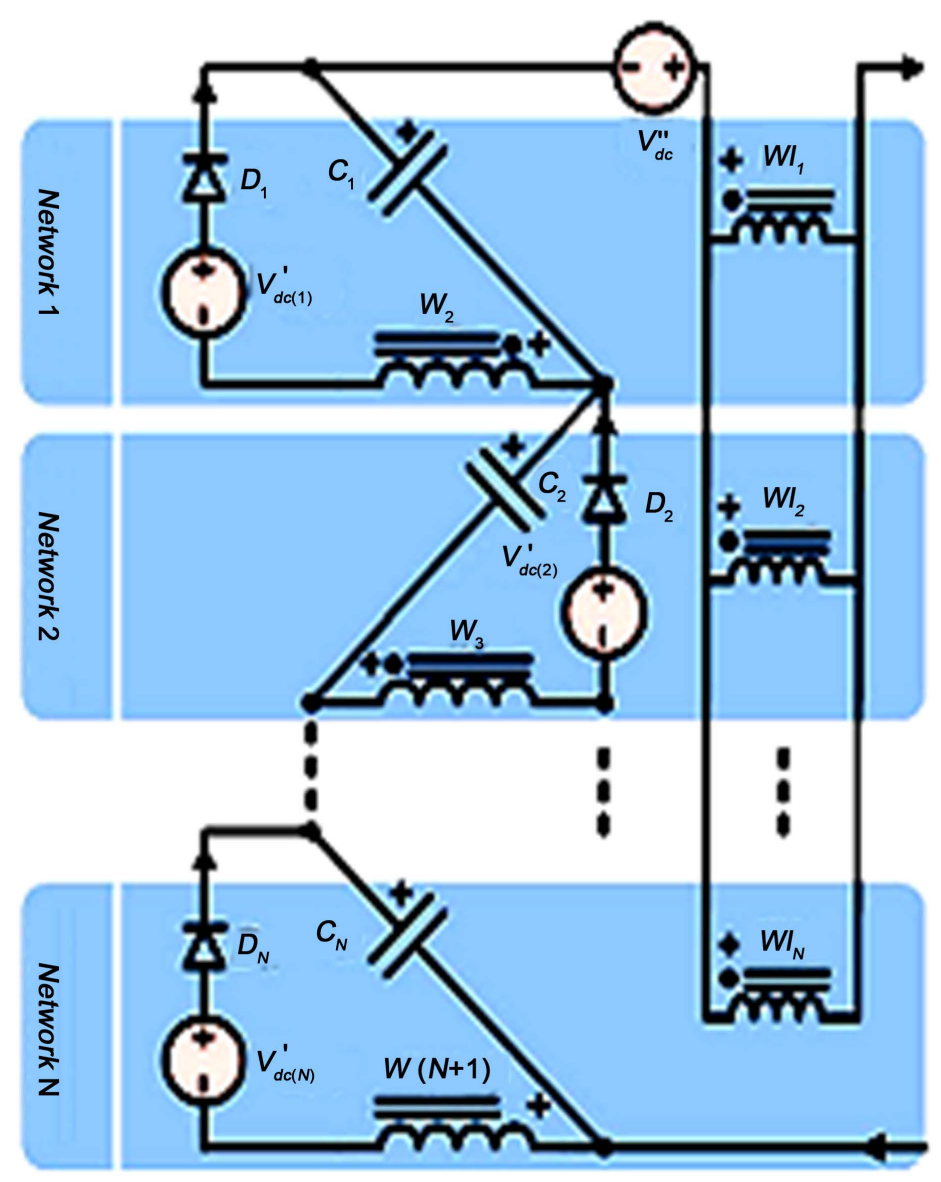

Figure 2. Proposed cascaded multi cell trans-Z-source network. 


\section{Methodology}

The variable speed wind turbine driven by permanent magnet synchronous generator is modeled by using MATLAB/SIMULINK. In general this integration to grid has a back to back converter with DC link.

The proposed methodology of this paper is given as a block diagram Figure 3. The block diagram description follows as; the variable speed wind turbine is driven by Permanent Magnet Synchronous Generator (PMSG). The permanent magnet synchronous machine is made to run as a synchronous generator by running the machine in negative torque. Since the speed is variable a constant output is not possible and it is oscillating according to the wind. This variable speed AC output is converted to DC by the use of diode rectifier.

This low DC voltage is boosted up without a DC-DC converter by cascade multi cell trans-Z-source inverter which works on the principle of shoot through process. During shoot through state any two switches of same phase leg is conducting by which DC voltage is boosted. The boost voltage is limited in order to save the switches from the damage as it is made to boost high voltage since the switches will be turned on for a long time. After the duty cycle of shoot through ratio the CMC inverter act as a normal inverter feeding the variable load. When variable load arrive into act the output from the inverter gets dip. In order to supply the required power to the load and to improve

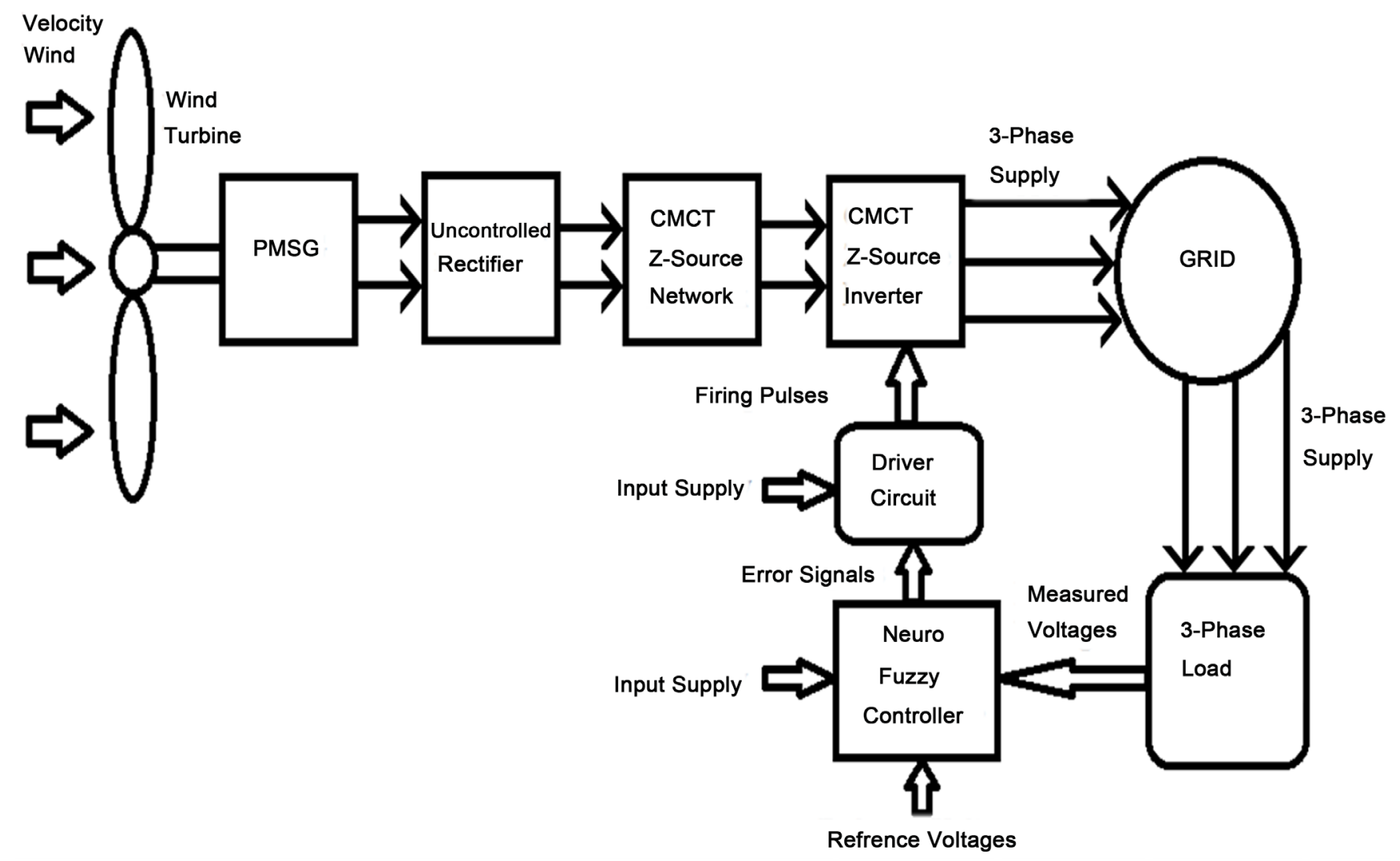

Figure 3. Proposed simulink model block diagram. 
the power quality a fuzzy logic control is used. The fuzzy controller has two inputs, error and change in error. The output is compared with a reference voltage to produce the error which is fed into the fuzzy controller. According to the variation in inverter output the fuzzy controller generates the pulse signals which control the inverter to generate required output voltage. Therefore we can provide superiority of power and the power quality has been improved.

The proposed methodology of this paper is given as a block diagram Figure 4. The block diagram description follows as; the variable speed wind turbine is driven by Permanent Magnet Synchronous Generator (PMSG). The permanent magnet synchronous machine is made to run as a synchronous generator by running the machine in negative torque. Since the speed is variable a constant output is not possible and it is oscillating according to the wind. This variable speed AC output is converted to DC by the use of diode rectifier.

This low DC voltage is boosted up without a DC-DC converter by cascade multi cell trans-Z-source inverter which works on the principle of shoot through process. During shoot through state any two switches of same phase leg is conducting by which DC voltage is boosted. The boost voltage is limited in order to save the switches from the damage as it is made to boost high voltage since the switches will be turned on for a long time. After the duty cycle of shoot through ratio the CMC inverter act as a normal inverter feeding the variable load. When variable load arrive into act the output from the inverter gets dip. In order to supply the required power to the load and to improve the power quality a fuzzy logic control is used. The fuzzy controller has two inputs,

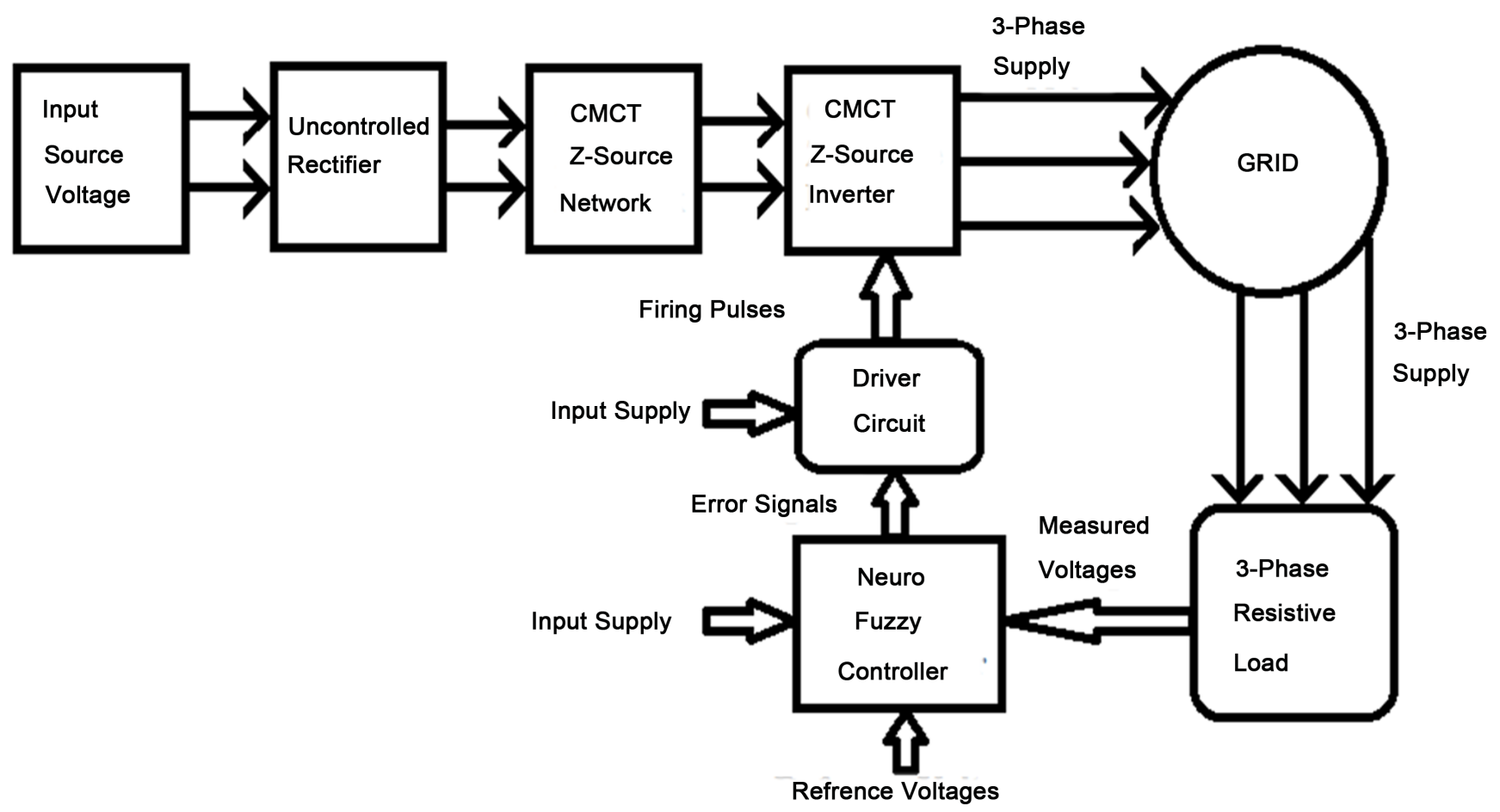

Figure 4. Proposed hardware model block diagram. 
error and change in error. The output is compared with a reference voltage to produce the error which is fed into the fuzzy controller. According to the variation in inverter output the fuzzy controller generates the pulse signals which control the inverter to generate required output voltage. Therefore we can provide superiority of power and the power quality has been improved.

\subsection{Cascaded Multicell Trans-Z-Source Inverter}

The reason for recommending the trans-Z-source circuits (and others) is mainly to produce a higher voltage boost using a higher transformer turns ratio $\gamma$. With transformer, some components would subsequently experience better steady-state voltage or current stresses depending going on the windings to which they are connected. The transformer itself capacity be tougher to intend too with wonderful magnetic coupling, low-leakage inductances and resistances still being the goals to accomplish. A few deviations from perfect coupling will lead to large transient over voltages caused by the contravention of currents. Make possible to happen with current through $W_{1}$ when entering a non shoot-through null state and current through $W_{2}$ when entering a shootthrough state. Avoiding the over voltages would require interrupted energy from one winding to be transferred to the other during great coupling.

A professionally coupled transformer is, therefore, a basic necessity for trans-Zsource inverters. Moreover over voltages, extreme high immediate current force run during winding $W_{1}$ and capacitor $C$ when in the shoot through state (not qualified by $W_{2}$ and diode $D$ ). Such high current is cause by the brash transfer of energy from $W_{2}$ to $W_{1}$ while the input diode $D$ reverse biased. A simple way to resolve it is to connect multiple capacitors and windings in parallel which, unlike series correlation, will not outstandingly make difficult the circuit operation in practice. More elaborated conversation about multiple mechanisms is continued in the following section with mutually series and parallel connections taken into consideration (Figure 5).

The resulting CMC trans-Z-source inverter is shown, which clearly does not have any direct series connection. No balancing resistors and sufferers are needed, meaning that the inverter is likely more efficient than the direct series-connected circuit shown. The CMC inverter would however still require parallel connections of windings W $1 k$ ( $k$ $=1$ to $N$ ) and capacitors to direct the flow of high immediate current during Shoot through. Such parallel associations will not be a concern in practice, unlike series connections. Resultant gain expressions for the CMC inverter can then be determined by analyzing the shoot-through and non-shoot-through states separately, before averaging them to arrive at the final expressions.

$$
\begin{gathered}
w 1=\sum_{\sigma=1}^{N} V_{c \sigma}+V_{d c}^{\prime \prime} \\
v_{W(k+1)}=\gamma_{k+1} v_{w 1},
\end{gathered}
$$

Heir correspondences when in the non shoot through state with all diodes conducting can be written as, 


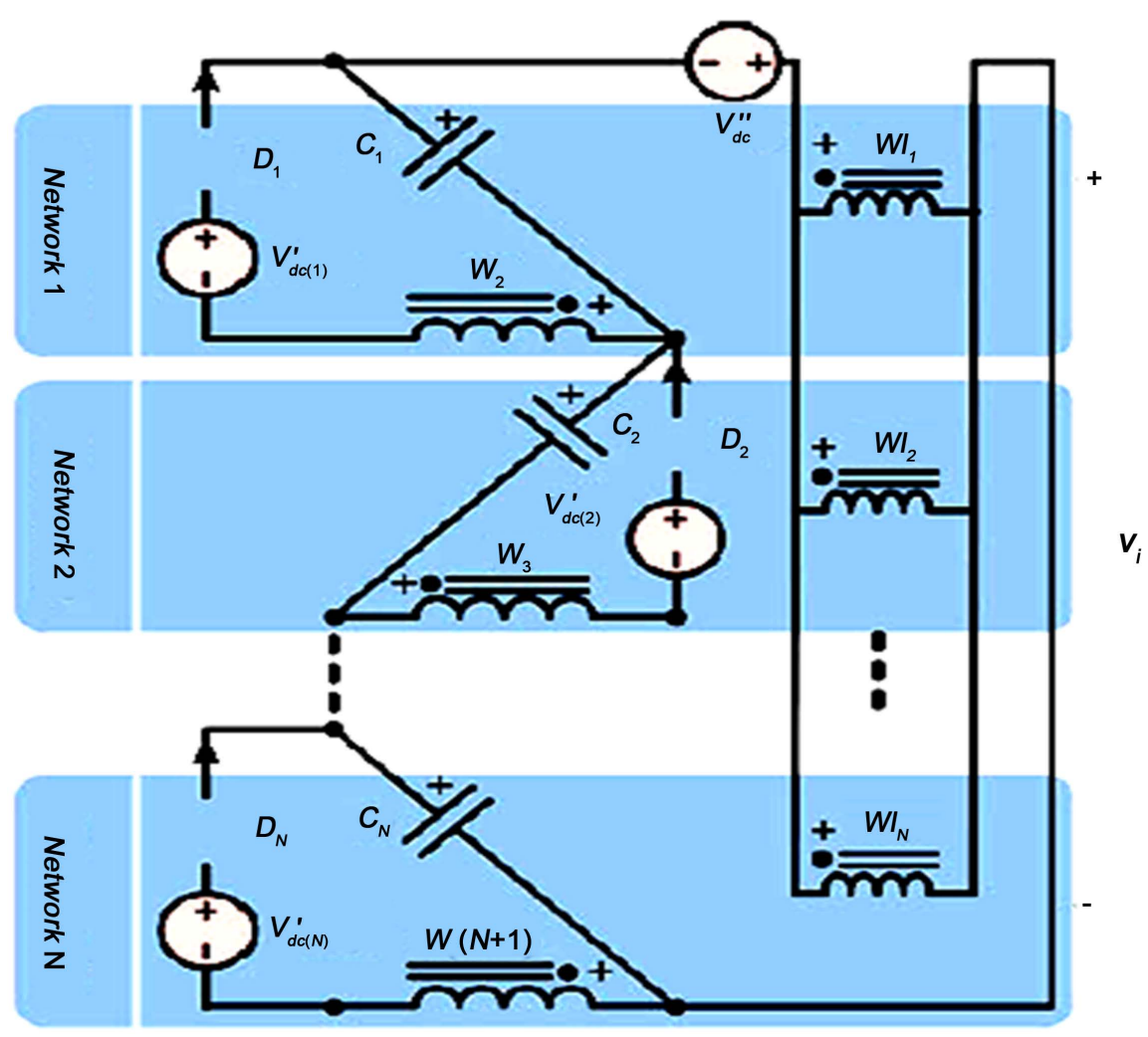

(a)

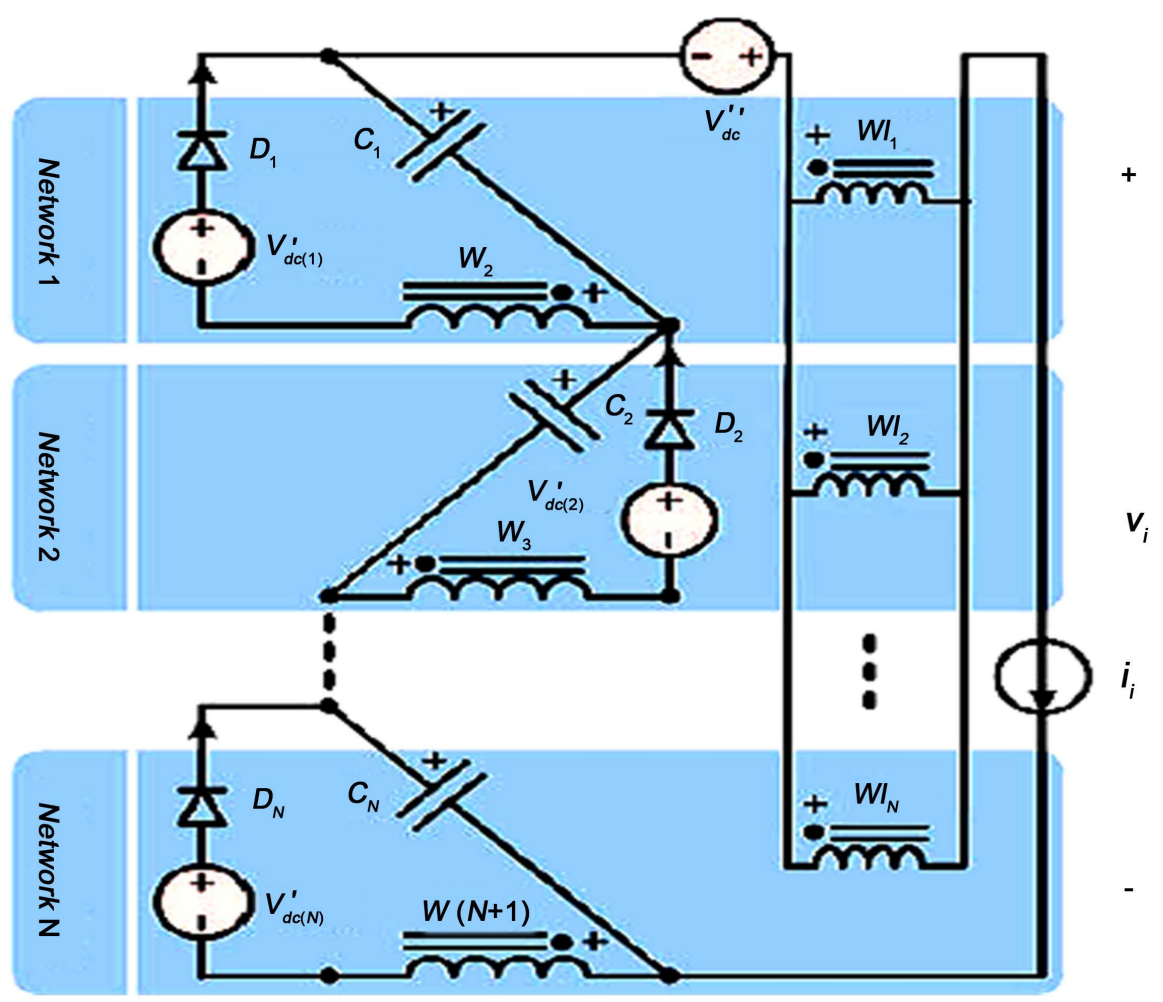

(b)

Figure 5. (a) Shoot-through and (b) non shoot-through states. 


$$
\begin{gathered}
v_{w 1}=v_{w(k+1)} / \gamma_{k+1} ; \\
v_{w(k+1)}=V_{d c(k)}^{\prime}-V_{C k}, \\
V_{C k}=\gamma_{k+1} d_{S T}\left\{\frac{V_{d c}^{\prime}+V_{d c}^{\prime \prime}}{1-(\gamma T+1) d_{S T}}\right\}+V_{d c(k)}^{\prime} \\
\gamma T=\sum_{\sigma=1}^{N} \gamma \sigma+1 ; \\
V_{d c}=\sum_{\sigma=1}^{N} V_{d c(k)}^{\prime} .
\end{gathered}
$$

Considering non shoot-through state, the peak dc-link voltage and peak ac voltage amplitude can be written as,

$$
\begin{gathered}
V_{i}=\frac{V_{d c}^{\prime}+V_{d c}^{\prime \prime}}{1-(\gamma T+1) d_{S T}} . \\
V_{a c}=\frac{0.5 M\left(V_{d c}^{\prime}+V_{d c}^{\prime \prime}\right)}{1-(\gamma T+1) d_{S T}} . \\
d_{S T}<1 /(\gamma T+1) .
\end{gathered}
$$

\subsection{Neuro Fuzzy Controller}

In this pasture of artificial intelligence, neuro-fuzzy refers to combinations of artificial neural networks and fuzzy logic systems. Neuro-fuzzy was planned by J. S. R. Jang. Neuro-fuzzy hybridization results in a jumble intellectual arrangement that synergizes these two techniques by combining the human-like investigation style of fuzzy systems with the learning and connectionist arrangement of neural networks. Neuro-fuzzy hybridization is widely termed as Fuzzy Neural Network (FNN) or Neuro-Fuzzy System (NFS) in the journalism. Neuro-fuzzy system (the more popular term is used in future) incorporates the human-like learning style of fuzzy systems through the use of fuzzy sets and a linguistic model consisting of a set of IF-THEN fuzzy rules. The main power of neuro-fuzzy systems is that they are worldwide approximates with the competence to implore interpretable IF-THEN rules. The potency of neuro-fuzzy systems involves two ambiguous supplies in fuzzy modeling: interpretability versus accuracy. In apply; one of the two properties prevails. The neuro-fuzzy in fuzzy modeling examine field is divided into two areas: linguistic fuzzy modeling that is listening carefully on interpretability, primarily the Mamdani model; and exact fuzzy modeling that is alert on truth, mainly the Takagi-Sugeno-Kang (TSK) model. Still though habitually implicit to be the awareness of a fuzzy system through connectionist networks, this term is also used to describe some additional configurations including:

Deriving fuzzy rules from skilled RBF networks.

$>$ Fuzzy logic based modification of neural network training parameters.

Fuzzy logic criteria for increasing a network range.

$>$ Realizing fuzzy membership function during clustering algorithms in unconfirmed learning in SOMs and neural networks and Representing fuzzification, fuzzy inference and defuzzification during multi-layers feed-forward connectionist network. 
It must be sharp out that interpretability of the Mamdani-type fuzzy systems can be vanished. To improve the interpretability of neuro-fuzzy systems, confident measures must be taken, in which essential aspects of interpretability of neuro-fuzzy systems are moreover discussed. A modern examine line addresses the data stream mining case, where neuro-fuzzy systems are consecutively updated with new arriving samples on demand and on-the-fly. Thereby, system updates do not only include a recursive adjustment of model parameters, but also a dynamic progress and pruning of model components (neurons, rules), in order to handle concept drift and enthusiastically changing system behavior adequately and to keep th systems/models "up-to-date" anytime. Supreme surveys of diverse growing neuro-fuzzy system Pseudo outer-productbased fuzzy neural networks ("POPFNN") are relations of neuro-fuzzy systems that are based on the linguistic fuzzy model. Three members of POPFNN live in the journalism:

$>$ POPFNN-AARS(S), which is based on the Approximate Analogical Reasoning Scheme.

$>$ POPFNN-CRI(S), which is based on commonly established fuzzy Compositional Rule of Inference.

POPFNN-TVR, which is based on Truth Value constraint.

The "POPFNN" building is a five-layer neural system where the layers from 1 to 5 are called: input linguistic layer, condition layer, rule layer, ensuing layer and output linguistic layer. The fuzzification of the inputs and the defuzzification of the outputs are similarly performed by the input linguistic and output linguistic layers while the fuzzy inference is reciprocally performed by the rule, situation and outcome layers. The knowledge process of POPFNN consists of three phases:

$>$ Fuzzy membership generation.

Fuzzy rule identification.

$>$ Supervised fine-tuning.

A variety of fuzzy membership invention algorithms can be used: culture Vector Quantization (LVQ), Fuzzy Kohonen Partitioning (FKP) or Discrete Incremental Clustering (DIC). Usually, the POP algorithm and its variant Lazy POP are used to categorize the fuzzy rules. These techniques of artificial intelligence based in fuzzy logic and neural networks are habitually functional together. This reasons to merge these two paradigms come out of the difficulties and inherent boundaries of each remote paradigm. Generically, while they are used in a mutual way, they are called Neuro-Fuzzy Systems. This term, however, is frequently used to allocate a specific type of system that integrates both techniques. This type of system is characterized by a fuzzy system where fuzzy sets and fuzzy rules are familiar using input output patterns. The several implementation of this neuro-fuzzy systems, where as the author defined its personal model. This commentary summarizes a general vision of the area unfolding the most known hybrid neuro fuzzy techniques, its advantages and disadvantages. The modern techniques of artificial intelligence have found application in almost all the fields of the human acquaintance. However, a great stress is given to the accurate sciences areas; perhaps the major expression of the success of these techniques is in trade field. These 
two techniques neural networks and fuzzy logic are many times functional together for solving engineering problems where the standard techniques do not supply an easy and precise solution.

The neuro-fuzzy expression was born by the fusing of these two techniques. As each investigator combines these two tools in dissimilar Way, then, some confusion was twisted on the exact meaning of this term. Still there is no absolute compromise but in general, the neuro-fuzzy term means a type of system characterized for a similar configuration of a fuzzy controller where the fuzzy sets and rules are adjusted using neural networks modification techniques in an iterative approach among the data vectors (input and output system data). Such systems demonstrate two divergent habits of behavior. In a first phase, called learning phase, it behaves approximating neural networks to facilitate learns its internal parameters off-line. Afterward, in the implementation phase, it behaves like a fuzzy logic system. Unconnectedly, each one of these techniques enjoy advantages and disadvantages that, when varied together, theirs cooperage provides better results than the ones achieved with the use of each remote technique.

\section{Overview of Simulink Models and Discussions}

The Permanent Magnet Synchronous Generator is modeled for an output about $500 \mathrm{~V}$ AC. This generated output is rectified in to DC voltage by diode rectifier. The permanent magnet synchronous machine is made to run at negative torque by which the machine acts as a generator. The wind generator is controlled by pitch angle controller. Using Pitch angle control, we can maintain constant speed of the generator; blade can be adjusted continuously, based on air flow falling in the wind turbine blade. This network boost up the DC voltage with multiple winding having small turns ratio. The boost voltage can be defined by coupling factor. The inverter side can be implemented shoot through state, that time when the inductor and capacitor can be get charged in the maximum level. Further we can removed the shoot though state the DC voltage can be passing the IGBT based Multi Cell Trans-Z-Source inverter. The inverter supplies the boosted DC voltage in to required AC to supply the load. The firing pulses for the inverter are given using sinusoidal pulse width modulation. Fuzzy logic controller can be controls the firing pulses according to the variable loads. Here Fuzzy controller can be compared Actual and Reference inputs continuously, then only provided to firing signals. Here firing signals can be continuously changed, based on the customer Loads. The overall simulation model is done with fuzzy logic controlled to improve the power quality.

Using MATLAB/SIMULINK the permanent magnet synchronous generator is modeled and simulated with an output of $500 \mathrm{~V} \mathrm{AC}$ as shown in Figure 6. The PMSG output is rectified Figure 7, which converts the AC voltage into DC voltage. This low DC voltage is fed to the cascaded multi cell trans-Z-source network. This network steps up the DC voltage according to the boosting factor. Here the boosting voltage is near to $600 \mathrm{~V}$ since the switches may be in trouble and it will get damaged due to continuous operation of high boosting. So DC-DC conversion is done without a chopper or a boost 


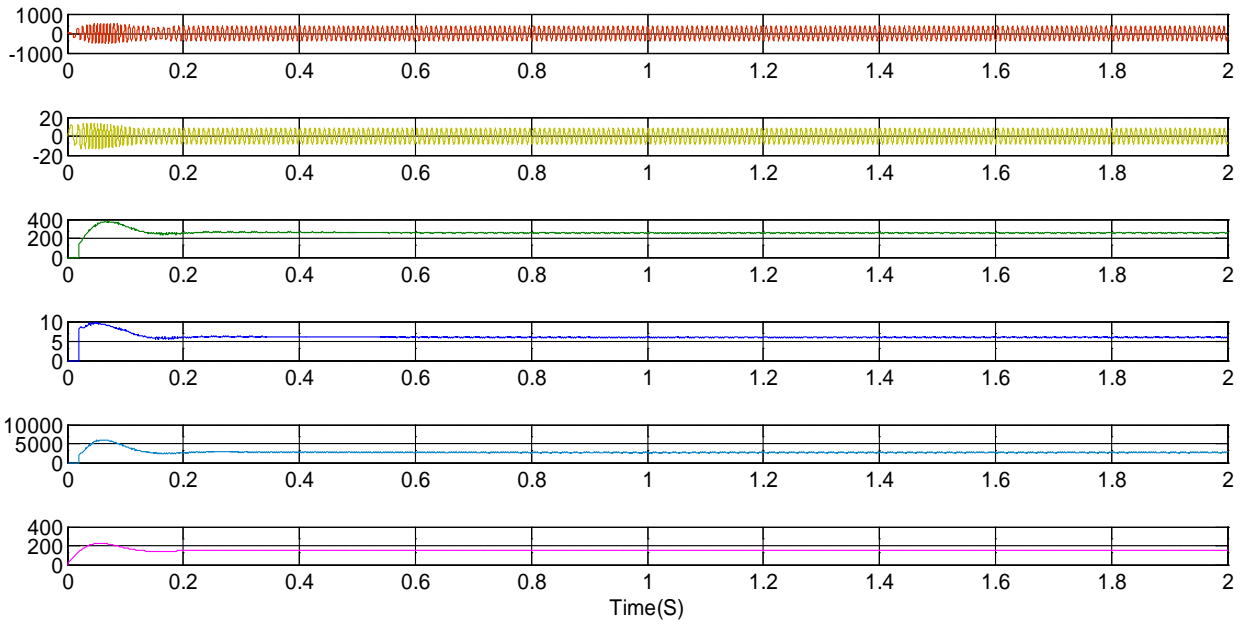

Figure 6. PMSG output.

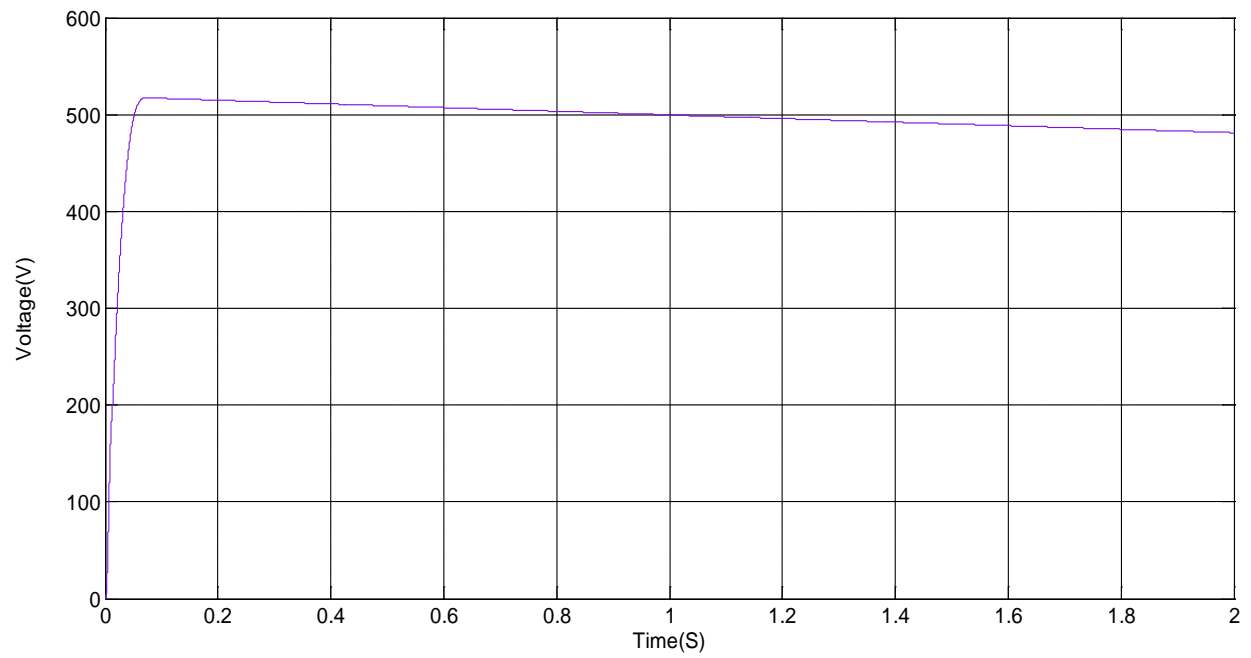

Figure 7. Rectified output.

converter Figure 8, that the boosted DC voltage convert into required AC voltage $440 \mathrm{v}$ refer Figure 9. The line voltage and Line current Figure 10 and Figure 11 and RMS voltage, phase voltage has been verified using Figure 12 and Figure 13. By using Matlab Simulink modeling neuro fuzzy system the harmonics level is reduced, less than $2 \%$ of conventional method, refer Figure 14 and Figure 15.

\section{Hardware Setup and Result}

Figure 16 shows the experimental setup of neuro fuzzy system based PMSG and Multi Cell Trans-Z-Source Inverter. Here $12 \mathrm{~V} \mathrm{AC}$ supply is given to the diode rectifier, and then the $12 \mathrm{~V}$ AC should be converted into $12 \mathrm{~V}$ DC. After AC to DC conversion, multi cell trans-Z-source inverter can be implemented by shoot through state. Before converting from $A C$ to $D C$, the DC side will be boosted up to $50 \mathrm{~V}$ DC. Further inverter can convert $50 \mathrm{~V} \mathrm{DC}$ to $50 \mathrm{~V}$ AC; required power can be transferred to the customer 


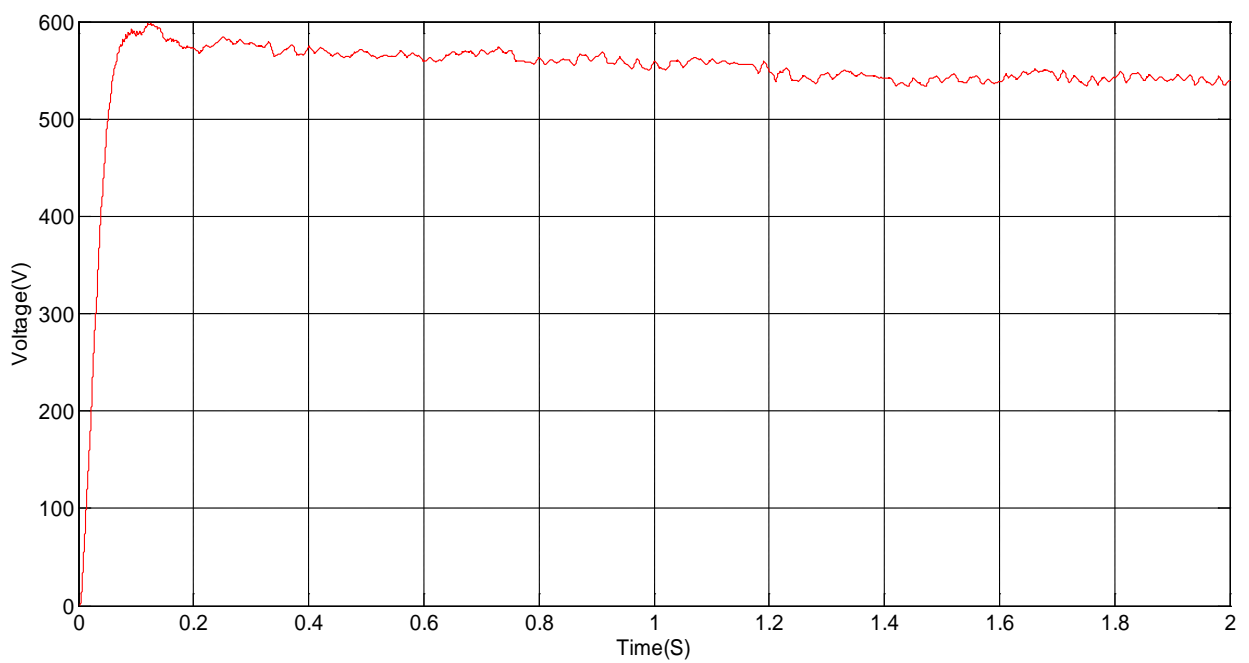

Figure 8. CMC network output.

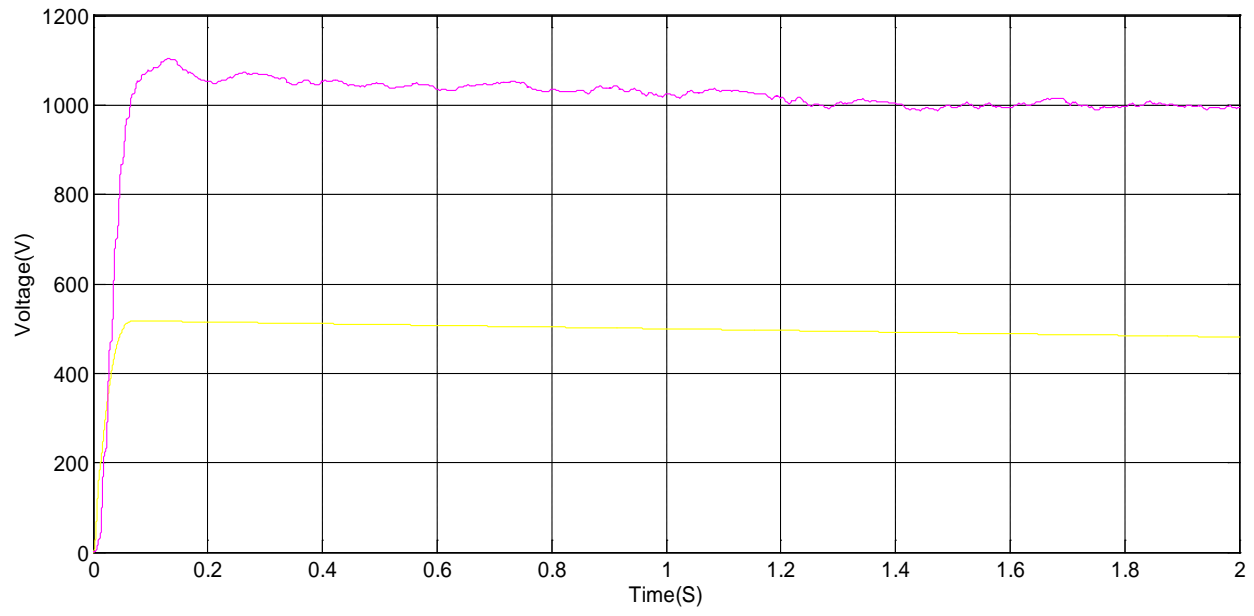

Figure 9. Input/output voltage.

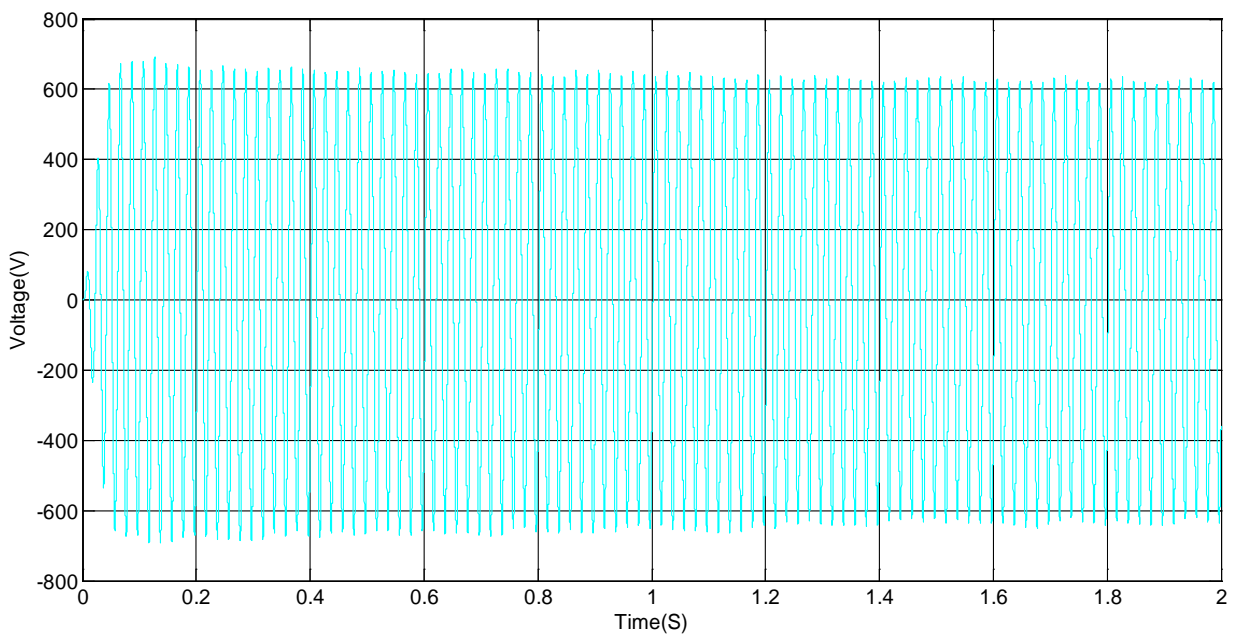

Figure 10. Line voltage. 


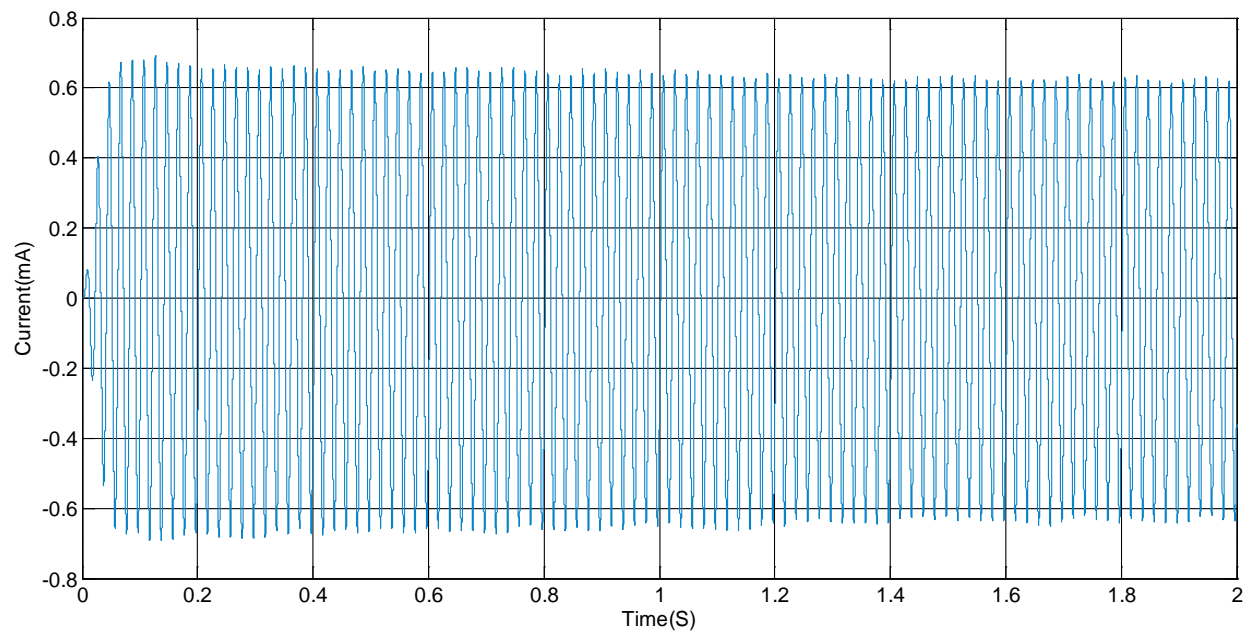

Figure 11. Line current.

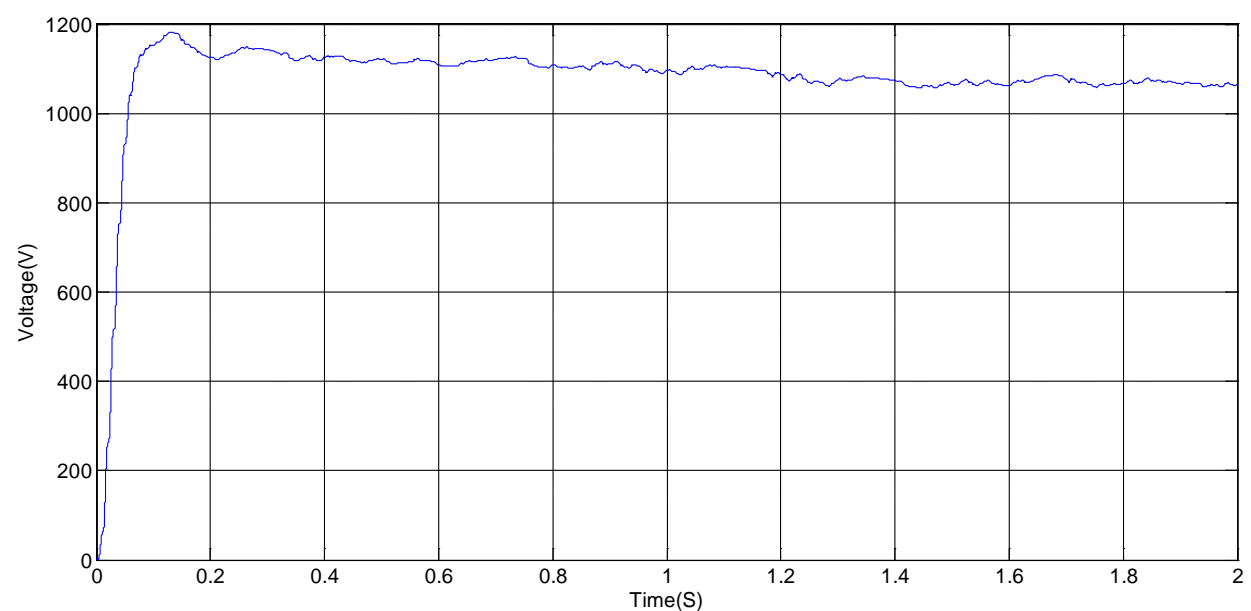

Figure 12. RMS phase voltage.

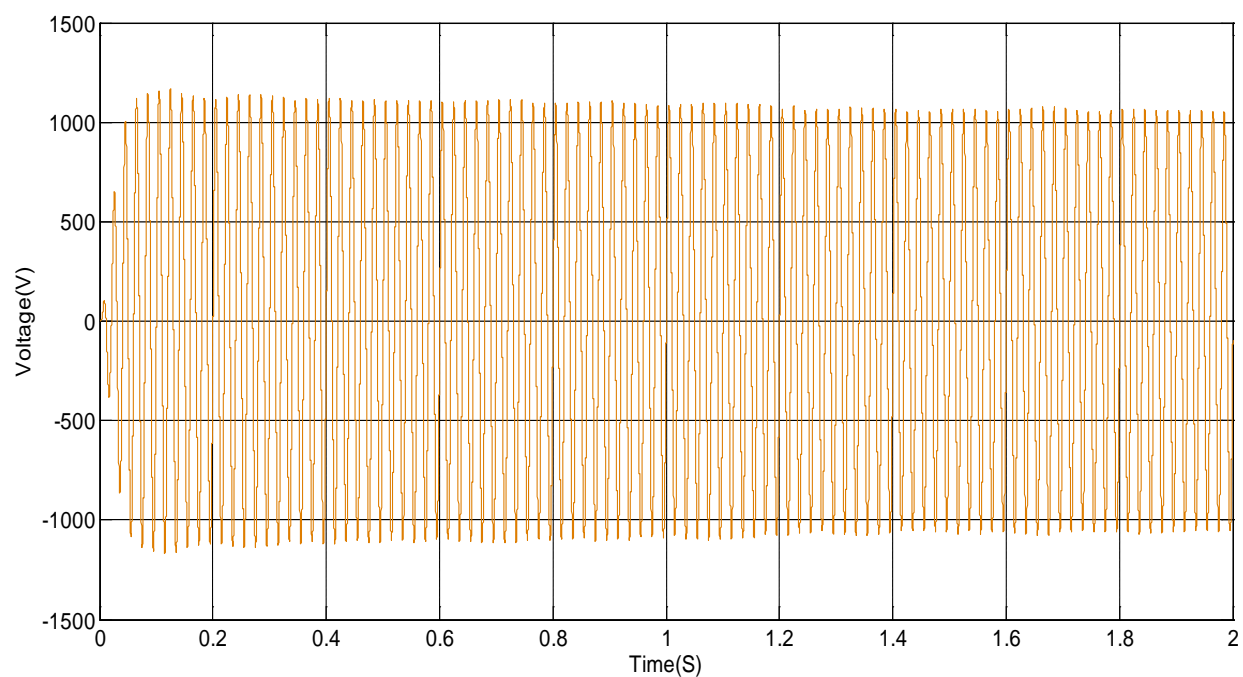

Figure 13. Phase voltage. 

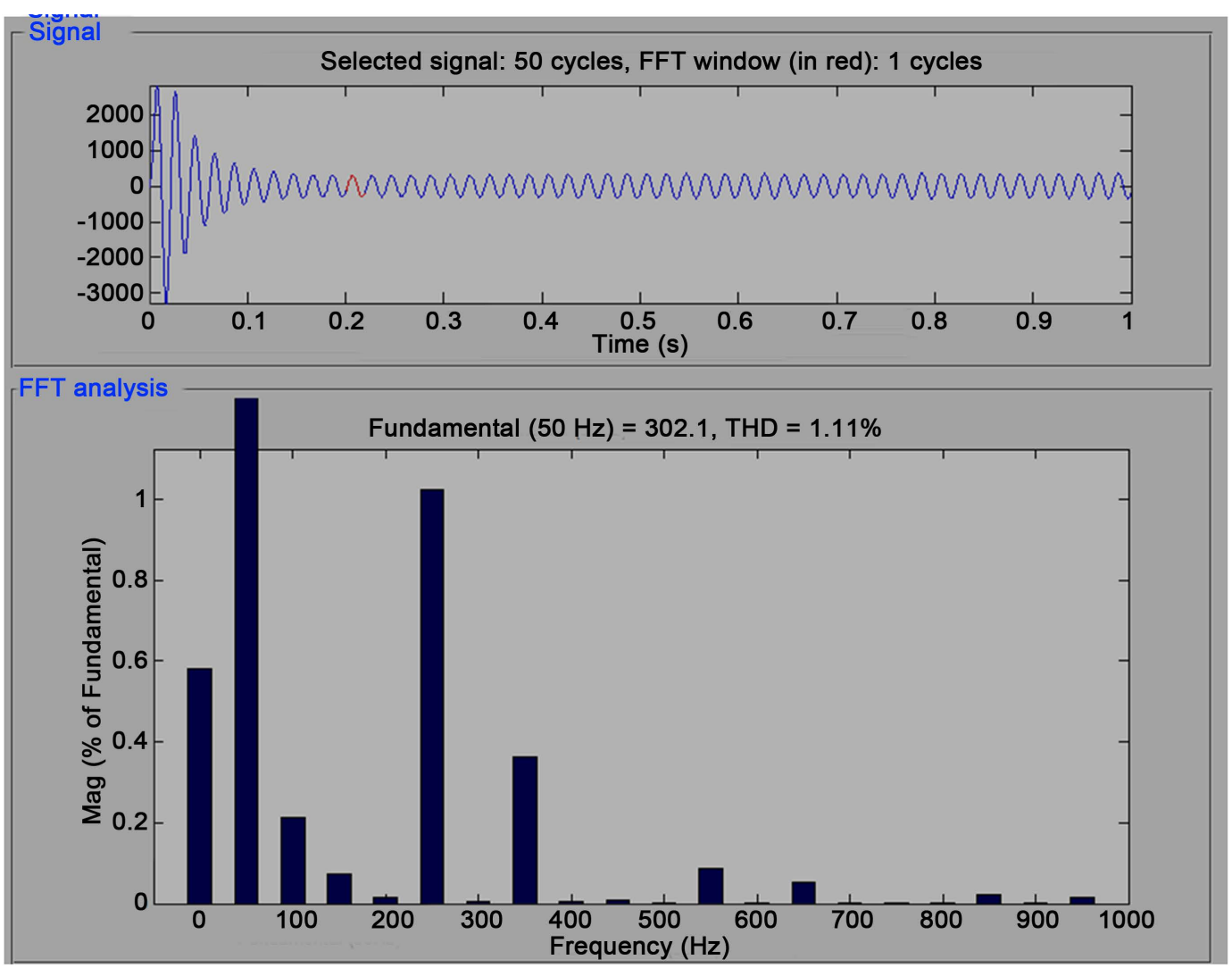

Figure 14. Line voltage harmonics.
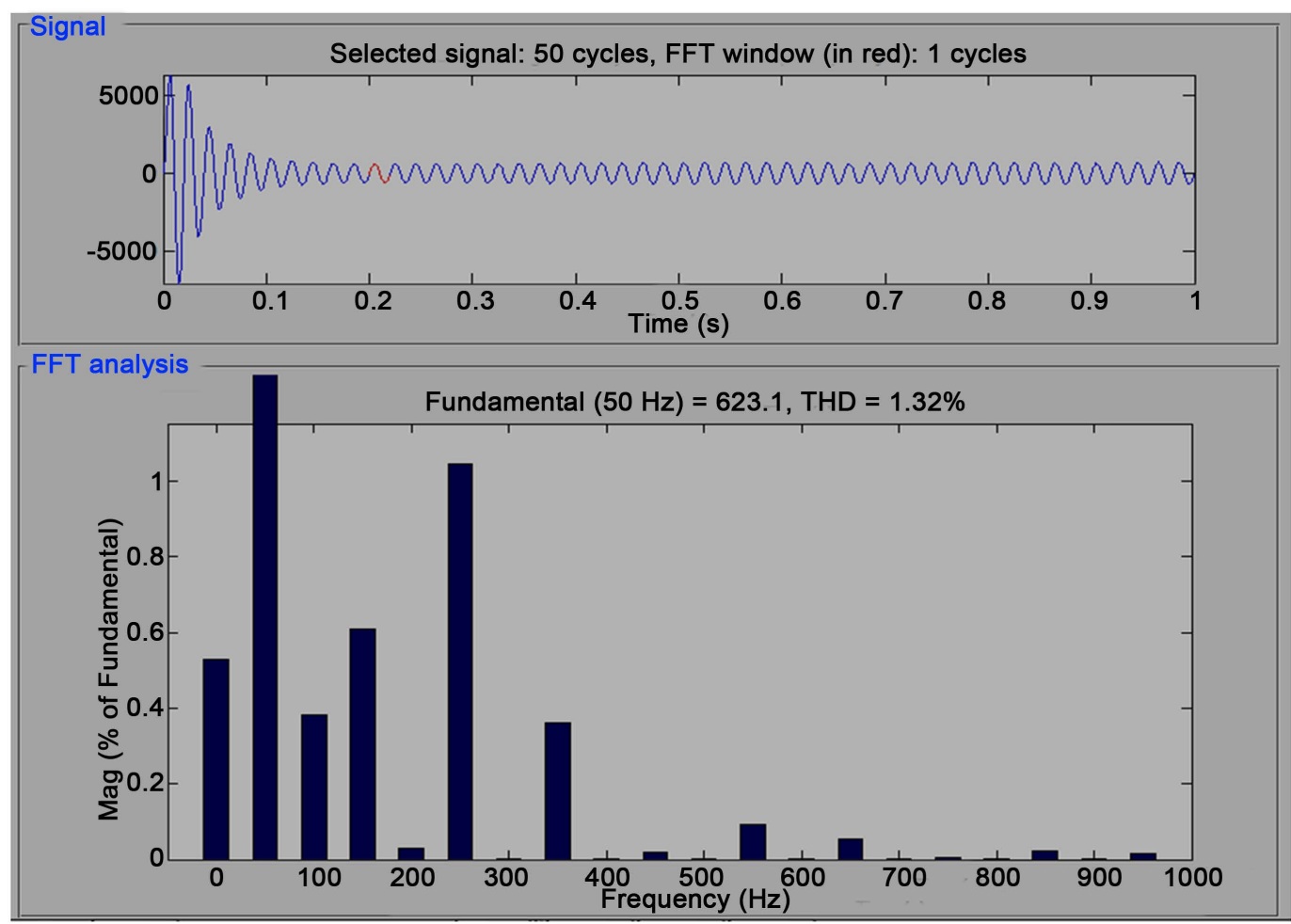

Figure 15. Phase voltage harmonics. 


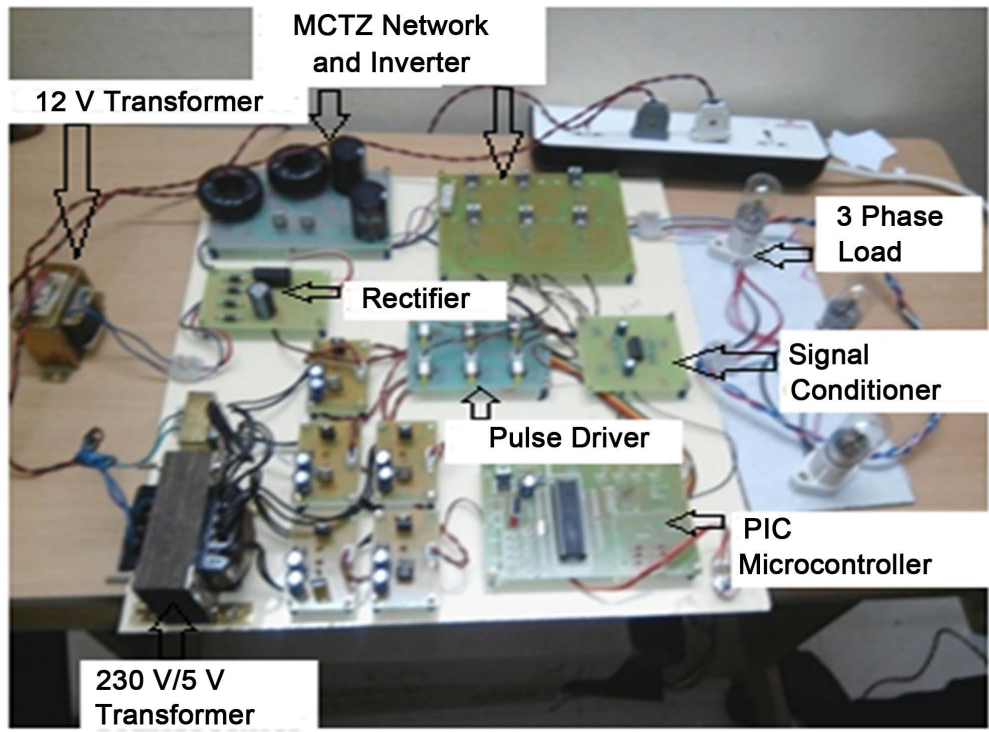

Figure 16. Experimental setup of multi cell trans-Z-source inverter.

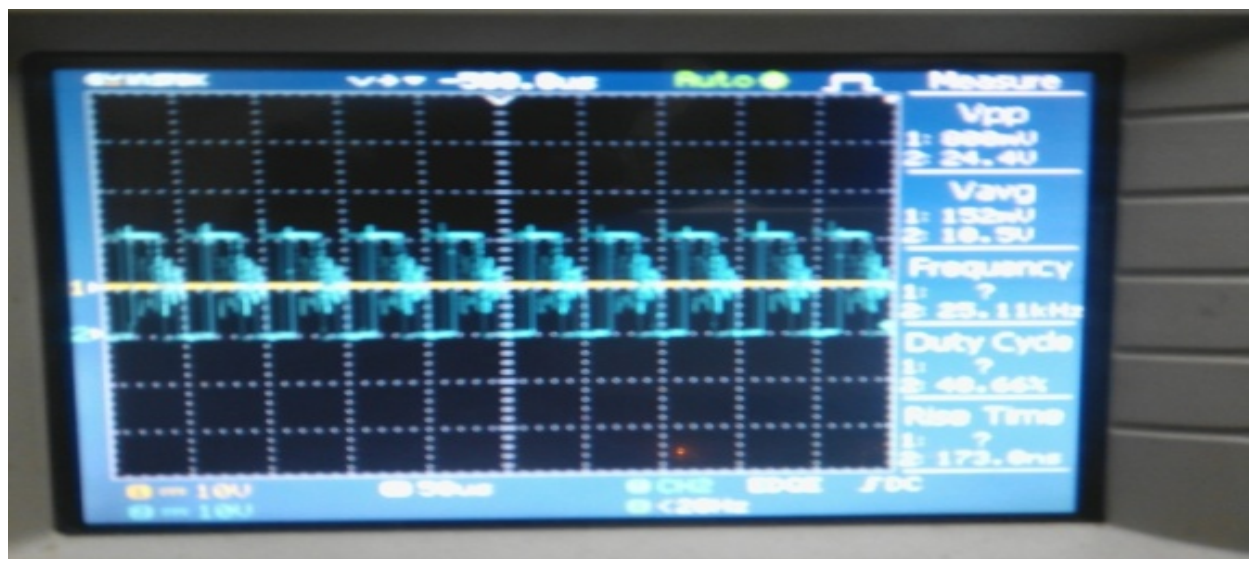

Figure 17. Hardware inverter output voltage.

load. Any load variation in the customer load side, the signal conditioner can operate and command is given to PIC microcontroller. At that time PIC Microcontroller can change command of pulse drive unit based on the error signals. So, that time the inverter output voltage can be changed and reactive power can be optimized. Here hardware inverter output voltage $50 \mathrm{~V}$ AC has been verified using DSO as shown in Figure 17.

\section{Conclusion}

In this paper a generic cascaded multi cell trans-Z-source inverter is presented. By using smaller coupled transformers with low turns ratio, the proposed inverter divides the instantaneous current stress among the windings. For $500 \mathrm{~V} \mathrm{AC}$ wind turbine output the proposed network is boosted up the DC voltage, which can be inverted to supply the variable load. With neuro fuzzy controller the inverter output is maintained about $1000 \mathrm{~V}$. The power quality issues for variable load are overcome by the superior neuro 
fuzzy controller, by which the power quality is improved. The harmonics was reduced below $2 \%$. The phase voltage harmonics is reduced to $1.32 \%$ and the line voltage harmonics was reduced to $1.11 \%$. The proposed hardware result could also be verified, if the input $12 \mathrm{~V} \mathrm{AC}$ converted into $12 \mathrm{~V}$ DC. Using shoot though state, the DC side can be boosted up to $50 \mathrm{~V}$ DC. Finally, the inverter output voltage is $50 \mathrm{~V}$ AC which can be supplied to the load. The performance of the proposed inverter has been verified in simulation results as well as hardware set up results.

\section{Acknowledgements}

This research was supported by Parents Mr. P. Elumalai, E. Rukmani and My Wife Dr. R. Vijaya Lakshmi and Esteems Guided Dr. C. Kumar. The corresponding author is grateful to Dr. C. Kumar and Dr. P. Suresh, for guiding him regularly to attend in the scientific planning, in Science Communication Programs/Scientific Research Paper Writings/International Workshops/National Seminars/Symposia.

\section{References}

[1] Rajendran, E., Kumar, Dr.C. and Ponkumar, G. (2013) LVRT Scheme of Wind Energy System Using Permanent Magnet Synchronous Generator and Hysteresis Current Controller. International Journal of Engineering Science and Technology, 5, 757-765.

[2] Rajendran, E., Kumar, Dr.C. and Ponkumar, G. (2013) LVRT Scheme of Wind Power System Modulation. International Journal of Engineering Science and Innovative Technology, 2, 536-546.

[3] Rajendran, E., Kumar, Dr.C. and Rajeshkanna (2013) Sliding Mode Controller Based Permanent Magnet Synchronous Generator with Z-Source Inverter for Variable Speed Wind Energy Translation Structure Using Power Quality Enhancement. International Journal of Computer Applications, 75, 6-11. http://dx.doi.org/10.5120/13113-0444

[4] Rajendran, E. and Kumar, Dr.C. (2013) Power Quality Improvement for Wind Energy Conversion System Using PMSG and Z-Source Inverter. International Journal of Engineering Science and Technology, 5, 100-108.

[5] Rajendran, E., Kumar, Dr.C. and Rajeshkanna (2013) Hysteresis Current Controller Based Grid Connected Wind Energy Conversion System for Permanent Magnet Synchronous Generator and Quasi Z-Source Inverter Using Power Quality Improvement. International Journal of Engineering and Technology, 5, 3819-3827.

[6] Rajendran, E. and Kumar, Dr.C. (2014) Power Quality Expansion for Grid Connected Wind Power System Using Permanent Magnet Synchronous Generator and Trans-Z Source Inverter. WSEAS Transactions on Power Systems, 9, 439-445.

[7] Rajendran, E., Kumar, Dr.C. and Vallarasu, R. (2015) Improvement of Power Quality for Grid Integrated Wind Power System Using PMSG and MCTZ Inverter. International Journal of Applied Engineering Research, 10. 
Submit or recommend next manuscript to SCIRP and we will provide best service for you:

Accepting pre-submission inquiries through Email, Facebook, LinkedIn, Twitter, etc. A wide selection of journals (inclusive of 9 subjects, more than 200 journals)

Providing 24-hour high-quality service

User-friendly online submission system

Fair and swift peer-review system

Efficient typesetting and proofreading procedure

Display of the result of downloads and visits, as well as the number of cited articles

Maximum dissemination of your research work

Submit your manuscript at: http://papersubmission.scirp.org/ 